LINDA DOLEŽÍ

DOI: $10.15290 / C R .2020 .30 .3 .03$

Masaryk University

ORCID: 0000-0003-4617-5490

PETRA KURFÜRSTOVÁ2

Masaryk University

ORCID: 0000-0002-2846-956X

IVETA ŠAFRATOVÁ3

Masaryk University

Georg-August-Universität Göttingen

ORCID: 0000-0001-8437-1738

\title{
Acquisition of polarity items in Czech children: An experimental study
}

\begin{abstract}
The Czech polarity items $i$ and ani are traditionally treated as English even. This paper deals with the acquisition of these polarity items in Czech children. These focus/scalar particles are specific for their sensitivity to probability. We aim to find out whether Czech children at primary school (junior school age) have already acquired $i / a n i$ and whether they are able to connect them correctly with alternatives on the scale of probability. The research was conducted with children from the second and the fourth grade at primary school. The paper represents an initial insight into this area since no similar research has been done in the Czech language so far.
\end{abstract}

Keywords: language acquisition; focus particles; scalar particles; experimental linguistics; language teaching.

\section{Introduction}

The particle even has been studied for its polarity and unlikelihood properties for a long time in several languages. Although many issues and questions concerning the behaviour of even still remain, it has been consistently shown that even is sensitive to the polarity of a sentence. Namely, there is even that can appear only in negative

1 Address for correspondence: Faculty of Arts, Masaryk University, Arne Nováka 1, 60200 Brno, Czech Republic. E-mail: dolezi@med.muni.cz

2 Address for correspondence: Faculty of Arts, Masaryk University, Arne Nováka 1, 60200 Brno, Czech Republic. E-mail: kurfurst.petra@gmail.com

3 Address for correspondence: Faculty of Arts, Masaryk University Arne Nováka 1, 60200 Brno, Czech Republic. E-mail: safratova@mail.muni.cz 
sentences, and therefore it is called Negative polarity item (NPI). In contrast, another even so-called Positive polarity item (PPI) may occur only in positive sentences (Krifka 1995). It is tough to detect this distinction in English since there is only one lexical item for even, see (1). However, there are two (or more) lexical items corresponding to even in many languages, e.g. German and Slovenian, among others. The Czech language also belongs to the group of languages where positive even and negative even are distinguished lexically.

(1) a. Even Charles came to the party.

b. Even Charles didn't come to the party.

Moreover, even is a focus sensitive particle that is associated with an F-marked expression. Polarity items, as well as focus sensitive particles, introduce alternatives (Rooth 1985). Basically, there is a set of alternatives, and the particle even picks out one alternative. ${ }^{4}$ The set of possible alternatives for the example (2-a) (repeated from (1-a) is in (2-b)). Note that the focused expression is highlighted in capital letters. The particle even chooses the one alternative in a certain way. The principles under which even selects an alternative are introduced in section 1.1.

(2) a. Even CHARLES came to the party.

b. the set of alternatives:

\{Charles\}

\{Jane\}

\{Richard\}

We have dealt with polarity and focus properties of even. In the next section we focus on even in Czech, we describe two main "evens" and show how they differ from each other. In section 3 we introduce two experiments on child acquisition of English even and in section 4 we present the experiment on child acquisition of Czech even and discuss the results.

\section{Theoretical background}

English even corresponds to (at least) two lexical expressions in Czech, namely $i$ and ani. ${ }^{5}$ These two items are nicely divided according to their polarity properties. The first Czech

\footnotetext{
4 Note that there is a requirement for the alternatives to be of the same semantic type. 5 In addition, the particles $i$ and ani may function as conjunctions and also marginally interjections. We leave these two other usages of the expressions aside and deal with $i$ and ani as particles only.
} 
even is $i$, and it is considered to be PPI since $i$ may occur only in affirmative sentences, and it is ungrammatical in negative sentences, see (3-a) and (3-b), respectively.

$\begin{array}{lllll}\text { (3) a. } & \text { Na večírek } & \text { přišel } & \text { i } & \text { Richard } \\ & \text { to party } & \text { come.3SG.PST } & \text { even } & \text { Richard }\end{array}$

'Even Richard came to the party.'

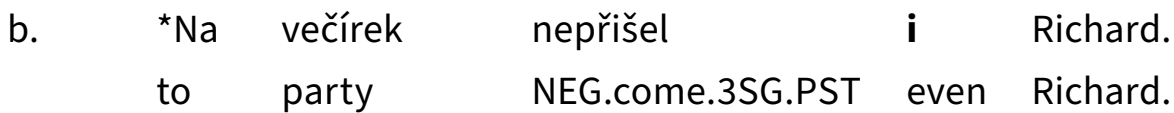

'Even Richard didn't come to the party.'

The second Czech even is ani. Historically, $i$ is claimed to be the basic, whereas ani is the modified version of $i$ in such a way that ani contains the basic $i$ and the negative element $-n$. (Lamprecht et al. 1986). This pattern nicely explains that ani is a negative counterpart of positive $i$. Since ani is NPI, it behaves in exactly the opposite way than $i$; it can appear only in negative sentences and it is ungrammatical in positive sentences, see (4-a) and (4-b), respectively.

\begin{tabular}{|c|c|c|c|c|c|}
\hline 4) a. & $\begin{array}{l}\mathrm{Na} \\
\text { to }\end{array}$ & $\begin{array}{l}\text { večírek } \\
\text { party }\end{array}$ & $\begin{array}{l}\text { nepřišel } \\
\text { NEG.come.3SG.PST }\end{array}$ & $\begin{array}{l}\text { ani } \\
\text { even }\end{array}$ & $\begin{array}{l}\text { Richard. } \\
\text { Richard }\end{array}$ \\
\hline & ‘Eve & Richard d & ome to the party.' & & \\
\hline b. & $\begin{array}{l}{ }^{*} \mathrm{Na} \\
\text { to }\end{array}$ & $\begin{array}{l}\text { večírek } \\
\text { party }\end{array}$ & $\begin{array}{l}\text { přišel } \\
\text { come.3SG.PST }\end{array}$ & $\begin{array}{l}\text { ani } \\
\text { even }\end{array}$ & $\begin{array}{l}\text { Richard. } \\
\text { Richard. }\end{array}$ \\
\hline
\end{tabular}

'Even Richard came to the party.'

Both $i$ and ani exhibit the same focus properties as English even. Unlike in English, Czech $i$ /ani have to occur immediately before the F-marked expression in a sentence. Since the occurrence of $i / a n i$ is sensitive to the polarity of sentences, they belong to the group called polarity items. Therefore, they introduce alternatives just like English even.

We do not go into details of the complicated theory of alternatives (for more details see Rooth 1985) but some background is needed for understanding our experiment. Concerning alternatives introduced by even the likelihood and entailment play a role. For simplification, only a closed set of alternatives are taken into account. Since even is generally considered to work with the likelihood, the alternatives are ordered on the probability scale, i.e. it is given by the context that one alternative is more likely or less likely than the other. Consequently, one alternative entails the other.6 Consider the following example:

6 Note that there is no entailment relationship between alternatives in some alternative sets, but still, the alternatives are ordered by probability because there is a likelihood relationship between them. 


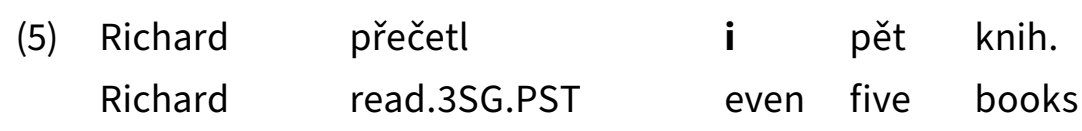

'Richard has read even five books.'

We can easily imagine that Richard is a student and he has to read books for an exam. The alternative set is restricted by the context where the maximum number of books he is supposed to read is five. Of course, many students do not read all the required books. The use of $i$ in (5) indicates that Richard has read the maximum number of the required books, and this is considered to be a significant achievement. The alternatives and their entailment and likelihood relationship are schematically captured in (6).

(6) a. the alternative set: $\{1$ book, 2 books, 3 books, 4 books, 5 books $\}$
b. $\quad$ the entailment relationship: read 5 books $\rightarrow$ read 4 books $\rightarrow$ read 3 books $\rightarrow$ read 2 books $\rightarrow$ read 1 book
c. $\quad$ the likelihood relationship: read 5 books $<$ c read 4 books $<$ c read 3 books $<$ c read 2 books $<$ read 1 book

There is the closed set of alternatives in (6-a), and the alternatives are in entailment relationship in such a way that the proposition Richard has read 5 books entails the proposition Richard has read 4 books and so on but not vice versa. Consequently, the alternative 5 books is the strongest alternative from the given set of alternatives since read 5 books entails all the other alternatives. At the same time, the alternative 5 books is the least likely alternative because reading 5 books is the most unlikely situation (again from the given alternative set).

We conclude that $i$ always associates with the least likely alternative and, simultaneously, the strongest alternative from the alternative set given by the context. Let's focus on ani and check whether it associates with an alternative of the same type. Now, consider the example with ani.

(7) Richard neprečetl
Richard ani jednu knihu.
'Richard hasn't read even one book.'

We imagine the same context, but Richard is a lazy student now. The alternative set remains the same. However, we observe that ani associates with a different alternative Since we use only alternative sets where there were both entailment and likelihood relationships be-
tween alternatives, we leave the alternatives without entailment relationship aside. 
than $i$. Let's first analyze the entailment and likelihood relationships between the alternatives before we make a conclusion.

(8) a. the alternative set: $\{1$ book, 2 books, 3 books, 4 books, 5 books $\}$

b. $\quad$ the entailment relationship: not read 1 book $\rightarrow$ not read 2 books $\rightarrow$ not read 3 books $\rightarrow$ not read 4 books $\rightarrow$ not read 5 books

c. the likelihood relationship: not read 1 book $<$ c not read 2 books $<$ $c$ not read 3 books $<c$ not read 4 books $<$ not read 5 books

The proposition Richard hasn't read 1 book entails the proposition Richard hasn't read 2 books and so on, but not vice versa.7 And, at the same time, the alternative not read 1 book is the least likely alternative because read 1 book is the minimum you can do. Imagine that a student wants to pass an exam. Then, it is more likely (and highly recommended) to read 2 books than only 1 book. Consequently, the alternative not read 1 book is the strongest alternative since it entails all other alternatives and it is also the least likely alternative from the contextually given alternative set.

The fact that ani associates with the strongest and the least likely alternative as well as $i$ is caused by the presence of negation in sentences containing ani. Negation intervenes between the F-marked expression and even and works as a scale reversing operator. In other words, negation reverses the scale of entailment and likelihood (for more technical details and formalizations see, e.g., Karttunen \& Karttunen 1977 and Crnič 2011). Therefore, both $i$ and ani associate with alternatives of the same type concerning entailment and likelihood, but the alternatives differ lexically.

The unified type of alternatives concerning entailment and likelihood for both $i$ and ani is well theoretically justified. Moreover, Šafratová (2018) focused on adults and their perception of structures with Czech even and showed that Czech adults treat $i$ /ani precisely as would be expected. Since even works with probability, which is part of pragmatics, the question that comes to mind is how and when adults learn how to use particles such as even. To solve this question we turned our attention to children and experimentally tested whether Czech children at a certain age have already acquired the particles $i / a n i$. Note that the acquisition of $i / a n i$ is not affected by Czech language education because according to two main education programs for primary education in Czech (Rámcový vzdělávací program pro základní vzdělávání, Školní vzdělávací program), no explicit attention is paid to the particles in primary education. However, there is no study

\footnotetext{
7 We are aware of the fact that this is not true since the proposition Richard hasn't read 1 book may, of course, mean that Richard has read 2 books. However, this is not relevant for explaining how the entailment and likelihood work for the particle even. For more details, we refer readers to the theory of scalar alternatives (Sauerland 2004; Fox \& Hack1 2006; Spector 2007, among others).
} 
about the acquisition of polarity items in Czech children we could build our research on. That is why we follow two relevant experimental research studies on child acquisition of English even that are introduced in the next section. Our experiment is presented in section 4.

\section{Child acquisition of English even}

As far as we know there are only two experimental research studies on child acquisition of English even, and interestingly, the two research studies came to different results. Both experiments tested English even in both affirmative and negative sentences. To avoid confusion we call even in positive sentences simply even, and even in negative sentences not even.

\subsection{Kim's experiment}

The first experiment was run by Kim (2011). She experimentally tested English even in two syntactic positions, namely the pre-subject position (9-a) and the pre-object position (9-b). We focus only on the results of even in the pre-object position since we tested Czech even in this syntactic position.

(9) a. Even Petr ate chocolate.

b. Petr ate even chocolate.

Kim tested 30 English speaking children aged 4-5 using a "guess who game". There were three pictures with even, and three pictures with not even, i.e. six tested pictures in total. Besides, there were six filler sentences and six control sentences to distract the children. The children were asked to listen to stories with pictures in such a way that the last sentence of a story contained even/not even. There were always three characters differing in size (the smallest one, the biggest one and a character of the middle size), and the task was to show the appropriate character in the picture based on the story. For instance, there was a picture of three different-size bears trying to reach a biscuit. Based on the pragmatic feature (height), children should have been able to recognize that the biggest bear has the greatest chance to reach the biscuit since the tested sentence contained not even.

Kim concludes from the experimental results that English children aged 4-5 have not acquired English even/not even yet. Moreover, the middle characters (options) did not appear as an answer at all. The number of children who answered correctly to each item and the total percentage of correct answers is in Table 1 (taken from Kim 2011: 96). 
Table 1. The correct answers

\begin{tabular}{|l|l|}
\hline & \\
\hline \multirow{2}{*}{ Affirmative even } & $41 / 90$ \\
\hline \multirow{2}{*}{ Negative even (not even) } & $45.6 \%$ \\
\hline
\end{tabular}

The question that comes to mind is why do English children have a problem with the usage of even? There are (at least) three possible answers or their combination: (i) The problem is lexical. Children have to learn the semantic meaning of even. (ii) The problem is syntactic. English even can stay quite freely in a sentence, unlike in Czech. (iii) The problem is pragmatic. Even has an unlikelihood presupposition and children have to count with the likelihood. Before we try to answer the question let's have a look at the second experiment on English even and compare the results from both experiments.

\subsection{MIT experiment}

Following Kim (2011), Newman et al. (2018) asked the following research questions: (i) How do children think when considering sentences with even? (ii) Why did none of the children choose middle options? (iii) What happens when we change scalar types when choosing different options?

They tested English speaking children aged 3-6. There were 88 children participating in the experiment in total. The experiment included four different scales: reaching stories, lifting/wight stories, fitting stories, and filling/capacity stories. The scales are presented in more detail in section 4. The authors also used a "guess who game" by telling stories and pictures. There were four pictures with affirmative even and four pictures with negative even (not even), therefore eight pictures in total. Moreover, the experiment contained four sample filler stories.

The experiment shows the polarity effect between even and not even. Children were more successful in tested sentences with not even, see Figure 1 taken from Newman et al. (2018). 


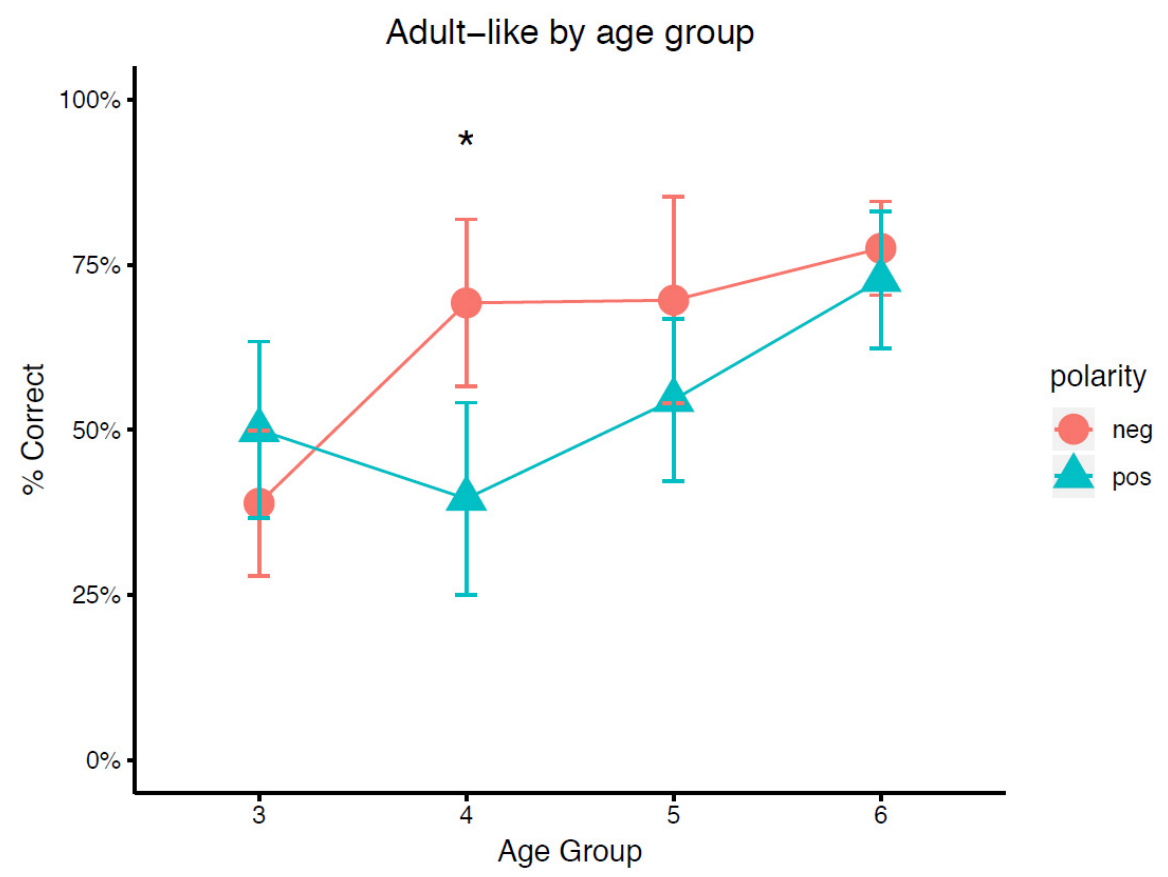

Figure 1. A plot of the rate of adult-like responses by age group, separated by polarity

Surprisingly, middle responses appeared in the results of the experiment, unlike the results of Kim's experiment. The results of MIT's experiment show that children answered not only the left or right option but also the middle option. Middle responses also show the polarity effect, but the opposite, i.e. middle responses, appeared more in tested sentences with even, see Figure 2, taken from Newman et al. (2018).

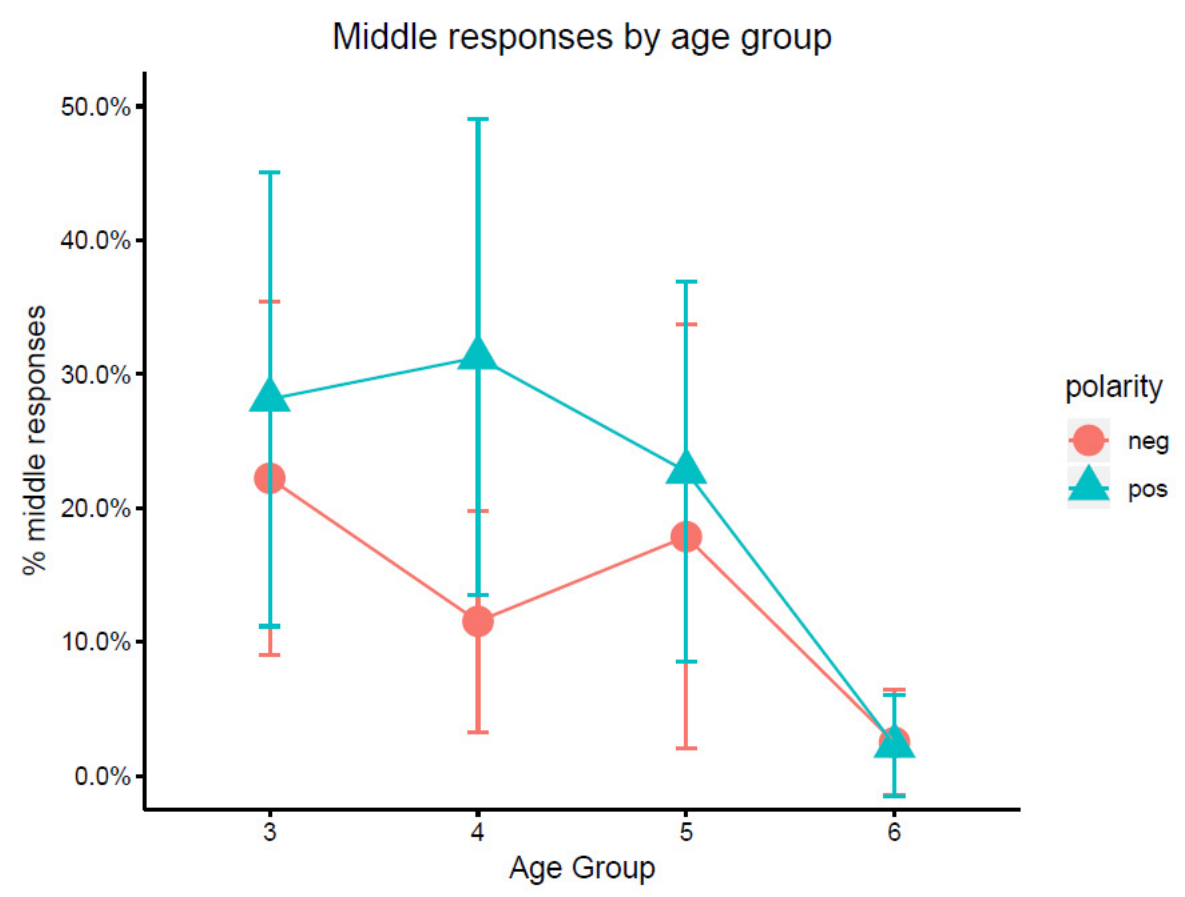

Figure 2. Middle responses decrease with age, and they decrease faster for negative even than positive even 
Overall experimental results show that:

1. children were more successful in tested sentences with not even;

2. middle responses appeared more in tested sentences with even;

3. children consider the likelihood, i.e. the unlikelihood presupposition, for even/not even;

4. children's usage of not even is close to the adults' usage of it;

5. children acquire not even at around 4 years of age, whereas they acquire even at around 6 years of age.

It is evident that Newman et al. (2018) gained different results than Kim (2011). However, we follow both experiments in our research, especially concerning the design of the experiment. We were aware of the fact that the experimental results of Czech i/ ani could differ from the results of English experiments because $i$ and ani are lexically distinguished as opposed to only one lexical item even in English. To the best of our knowledge there is no research on children acquisition of Czech scalar particles $i$ /ani, and therefore the experiment was designed as a "mapping territory" project.

\section{Experiment}

The main focus of our experiment was to find out whether children aged 7-10 have already acquired the $i /$ ani particles in their scalar function. 20 children from grade 2, and 20 children from grade 4 took part. As stated above, when designing the experiment, we followed similarly oriented research, in particular the study by Kim (2011) and with the kind permission of the authors also the experiment developed by MIT linguists Newman et al. (2018).

Four hypotheses were stated:

- children in grade 2 will not have adult-like or similar understanding of $i / a n i$ expressions;

- $\quad$ children in grade 4 will have acquired $i / a n i$ expressions fully;

- there will be middle variants of the responses, especially in grade 2 children;

- there will be a difference in the acquisition of $i$ and ani expressions.

\subsection{Procedure and participants}

We ran the experiment in two phases. In phase 1 we tested 20 adults to see whether our tasks are well designed and comprehensible and also to check whether the language phenomena we studied were fully acquired by adult speakers. In phase 2 we carried the experiment out with children (20 children age 7-10 from grade 2 and 20 children age 9-10 from grade 4). Children were chosen randomly by their teachers, parents had to provide their consent. The testing ran according to the same scenario as with the adults. Before the beginning they were informed about the form of the experiment the pictures of animals in three different sizes and the task - to choose to which animal 
the text relates to. The participants were not aware of the fact that they are taking part in research on scalar particles $i / a n i$, neither were shown any training pictures so that they were not biased. The accompanying text was read aloud, however, children could also read it for themselves. Their answers were noted down into answer sheets without stating explicitly to the participants whether their answers were correct or not so that their answers were not influenced by this information. One experiment with one person took approximately 10 minutes.

\subsection{Design and material}

We adapted thematic story areas created by Newman et al. (2018) and used the same number of items. Furthermore, we profited from their experience with testing and thus avoided possible problems. We created our own unique illustrations (Bukovjan 2019) and texts including the tested expressions $i$ /ani. The experiment consisted of two parts - the first part were stories testing $i / a n i$, the second part were filler stories that were meant to distract the participants' attention.

The individual pictures depicted animals of three different sizes in the given contextual situation (in the given thematic story) in the first experiment part. The context provided a pragmatics feature ensuring that only one animal should be chosen assuming that children interpret the sentences with $i / a n i$ pragmatically correctly.

The thematic story areas were as follows:

- Reaching stories: the motive is the effort to reach for something/somewhere;

- Lifting/weight stories: the motive is to try to pick up something;

- Fitting stories: the motive is to fit somewhere;

- Filling/capacity stories: the motive is an effort to fill something (e.g. a basket).

Every story area contained one picture testing the $i$-expression and one picture testing the ani-expression, there were 8 tested pictures together. An example of the illustrations and texts can be found below in Picture 1 and Picture 2.

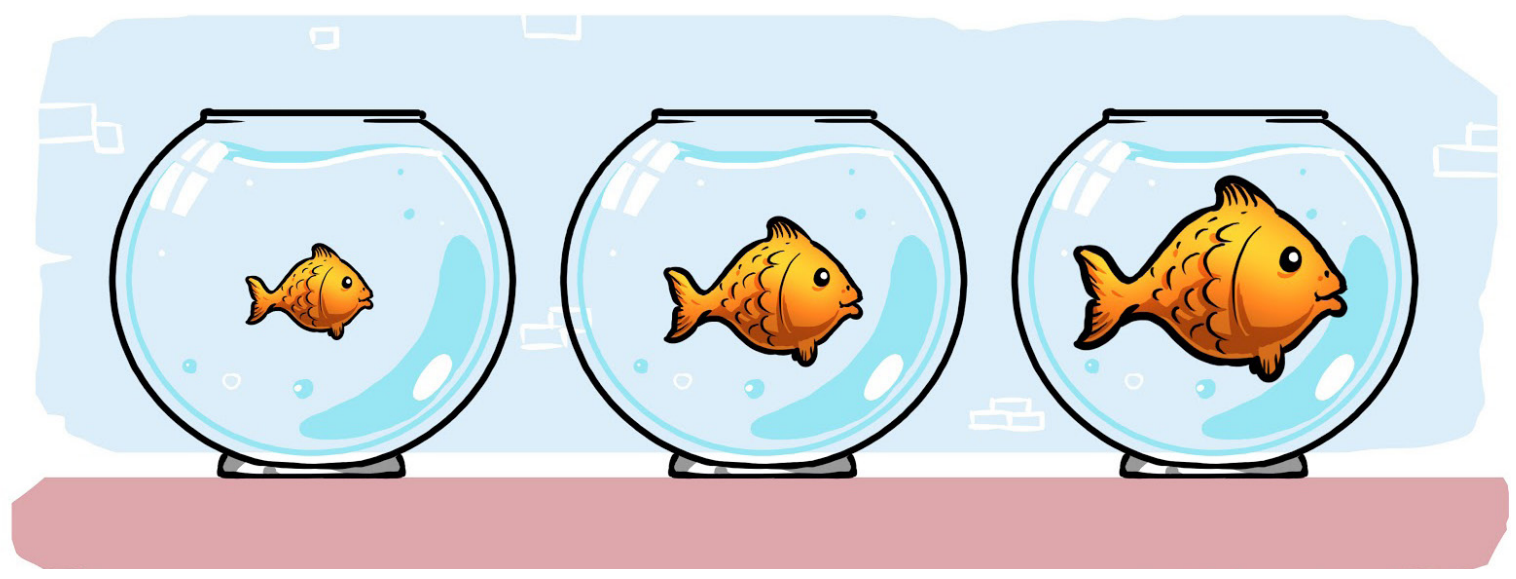

Picture 1: V prodejně rybiček zkoušeli, jak velká rybka se vejde do skleněného stolního akvária. Bylo tak prostorné, že se do něj vešla i Dona. Poznáš, která rybka je Dona? 
'In a fish shop they tried how big a fish could fit into a glass table aquarium. It was so spacious that even Dona could fit into it. Do you know which fish is Dona?'
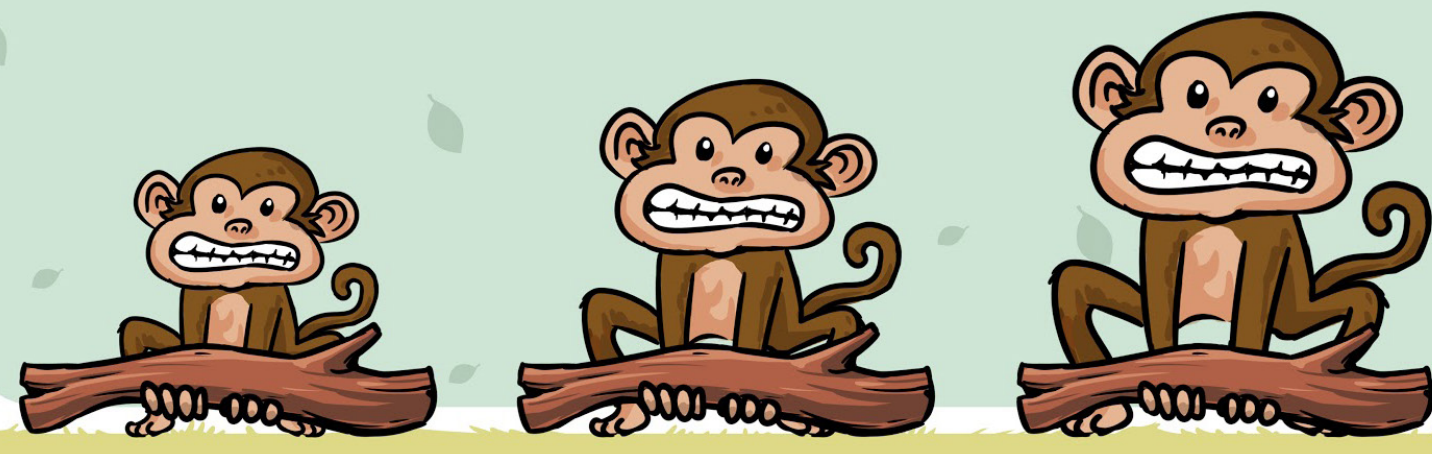

Picture 2: Opice se vsadily o trs banánů, že ze země zvednou velikou těžkou kládu. Kláda

byla ale tak moc těžká, že ji neuzvedl ani opičák Rocky. Poznáš, která z opic je Rocky?

'Monkeys bet a bunch of bananas that they will be able to lift a large, heavy log from the ground. But the log was so heavy that even Rocky didn't lift the log. Do you know which monkey is Rocky?'

In both examples of the test pictures, the accompanying text referred to the biggest animal (i.e. the biggest fish, the biggest monkey) because it is clear from the context that it is the least probable alternative (and with these the scalar particles bind). Generally speaking, the correct answers, however, were not only the biggest animals but also the smallest or the middle ones in the case of fillers. This is how we prevented the participants from guessing or seeing through the experiment.

In addition to tested pictures, we used four sample filler stories in the second part of the experiment. To prevent the children from observing a pattern in which the experiment works and find their own algorithm according to which they would answer, we ordered the pictures randomly so that two pictures of the same story category did not appear next to each other. All together there were 12 pictures accompanied by texts, i.e. 8 tested pictures and 4 filler pictures.

\subsection{Results}

The whole experiment was evaluated by several means ranging from the most ordinary descriptive statistics to proper statistical analyses using programming language $\mathrm{R}$ in RStudio. The responses were modeled in lmerTest, which is not a part of RStudio but it is a standard model and it was added as a package into the RStudio. By using such a wide range of statistical tools we tried to get as many pieces of information as possible. As to the results of the research carried out on adults - they were successful in completing 
the task in almost $100 \%$. Only in one case did an adult make a mistake probably due to lack of concentration rather than linguistic incompetence.

In children the results were as follows:

1. in the case of $100 \%$ success in all items testing $i / a n i$ as well as the fillers, the results were:

- grade 2: only $25 \%$ of children were $100 \%$ successful $(5 / 20)$

- grade 4: $55 \%$ of children were $100 \%$ successful (11/20)

2. the results of $100 \%$ success in tested $i /$ ani items (all together):

- grade 2: $30 \%$ of children were $100 \%$ successful

- grade 4: $60 \%$ of children were $100 \%$ successful.

From this perspective it seems that children in grade 4 were two times more successful than children in grade 2 . We also had a look at the number of mistakes made by children. Some of them made only one mistake which might have been caused by lack of attention or hesitation. In case we recalculated the results and included also the " 1 mistake children" the success rate would increase a lot (especially in grade 2):

- grade 2: $60 \%$ of children with almost $100 \%$ success

- grade 4: $75 \%$ of children with almost $100 \%$ success

3. Success rate was further analysed for every even-variant separately - $i$-variant and ani-variant. The results showed a higher success rate in items testing understanding $i$-variant in children from both grades. Both variants $-i$ /ani- were easier for children from grade 4, which might mean that they understand these expressions better. Nevertheless, the $i$-expression success rate was $65 \%$ in grade 2 , which already proves a very good understanding. On the other side, understanding aniexpression was in grade 2 only 40\%, which could mean that this expression is more difficult to acquire and is thus acquired later.

a) Results of items with $i$ :

100\% successful: a child correctly understood all items with $i$

- grade 2: $65 \%$ of children were $100 \%$ successful (13/20)

- grade $4: 80 \%$ of children were $100 \%$ successful (16/20)

b) Results of items with ani:

$100 \%$ successful: a child correctly understood all items with ani

- grade 2: $40 \%$ of children were $100 \%$ successful (8/20)

- grade 4: $65 \%$ of children were $100 \%$ successful (13/20).

4) We also compared the results according to their success rate in individual story areas. Every picture was evaluated as to the success rate separately for $i$ - and ani-expressions. This comparison showed a high success rate for both expressions and children in both grades seem to understand these two expressions well. Even though the partial results showed a difference between the two classes as well as the two expressions, the children responded correctly in about $80 \%$. 
Table 2. The success of children in each story in sentences with $i$. Story 1 = reaching stories, story 2 = lifting/weight stories, story 3 = fitting stories and story 4 = filling/capacity stories.

\begin{tabular}{|l|c|c|c|c|c|c|}
\hline & story 1 & story 2 & story 3 & story 4 & in total & \% \\
\hline grade 2 & $17 / 20$ & $17 / 20$ & $16 / 20$ & $18 / 20$ & $68 / 80$ & $85 \%$ \\
\hline grade 4 & $19 / 20$ & $17 / 20$ & $18 / 20$ & $20 / 20$ & $74 / 80$ & $93 \%$ \\
\hline
\end{tabular}

Table 3. The success of children in each story in sentences with ani.

Story 1 = reaching stories, story 2 = lifting/weight stories, story 3 = fitting stories and story 4 = filling/capacity stories 8

\begin{tabular}{|l|c|c|c|c|c|c|}
\hline & story 1 & story 2 & story 3 & story 4 & in total & \% \\
\hline grade 2 & $12 / 20$ & $15 / 20$ & $20 / 20$ & $16 / 20$ & $63 / 80$ & $79 \%$ \\
\hline grade 4 & $15 / 20$ & $18 / 20$ & $20 / 20$ & $16 / 20$ & $69 / 80$ & $86 \%$ \\
\hline
\end{tabular}

The preliminary summary is the following:

1) Children make fewer mistakes in sentences with $i$.

2) It is easier for children to understand sentences with $i$. Several possible explanations may affect the understanding of $i$. First, since ani interacts with negation, it might make ani more complex to understand. Second, the interaction with negation causes the reverse scale of likelihood and therefore both $i$ and ani associate with the least likely alternative. Third, the correct understanding of $i$ and ani depends on pragmatic abilities of children.

3) Children in both grade 2 and grade 4 have acquired both expressions $i$ and ani.

For getting a more detailed analysis we processed the obtained data in programming language RStudio. Answers were modified as follows:

- 1 - the expected responses (the least likely alternative)

- 0.5 - the middle option

- 0 - the opposite end of the scale (the most likely alternative).

To model the data we constructed a mixed linear model that tested whether the subjects' answers can be predicted from a condition (fixed effect) and whether the conditions differed in their statistical significance. There were following conditions:

1) 2-i: sentences with $i$ in grade 2

2) 2-ani: sentences with ani in grade 2

8 The attentive reader may notice that there is a relatively large difference between the success in story 1 and story 3 . Looking at success in the stories, we see a big drop between story 1 and other stories. There is not much difference in success between other stories. Since only story 1 seems to be problematic for children, we blame this story 1 for failure. Even though story 1 was based on the same principle as the other stories, children may have seen a difference between story 1 and others or children just did not like the story. Thanks to an anonymous reviewer for raising this point. 
3) 4-i: sentences with $i$ in grade 4

4) 4-ani: sentences with ani in grade 4.

The success rate of responses depending on the conditions is between $0-1$. The statistical differences between sentences with $i$ and sentences with ani were modeled in lmerTest. The model had one predictor, i.e., the reference level condition: 2-ani. The success of the other conditions was measured against the reference level condition. The output of the model is reported in Table 4. The $t$-value states how big the difference between two conditions is, the p-value says how likely it is that the difference between the two conditions is random. As we can see from the results, no fixed effects were statistically significant.

Table 4 . The statistical output

\begin{tabular}{|c|c|c|c|c|c|}
\hline \multicolumn{6}{|c|}{ Fixed effects: } \\
\hline & Estimate & Std. Error & df & t value & p value \\
\hline (Intercept) & 0.80000 & 0.05601 & 10.35250 & 14.283 & $3.81 \mathrm{e}-08 * * *$ \\
\hline Condition $2-\mathrm{i}$ & 0.06875 & 0.07754 & 9.60427 & 0.887 & 0.397 \\
\hline $\begin{array}{l}\text { Condition } \\
4 \text {-ani }\end{array}$ & 0.06875 & 0.05028 & 291.00007 & 1.367 & 0.173 \\
\hline Condition $4-\mathrm{i}$ & 0.13125 & 0.07754 & 9.60427 & 1.693 & 0.123 \\
\hline \multicolumn{5}{|c|}{ 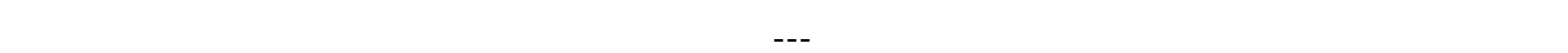 } & 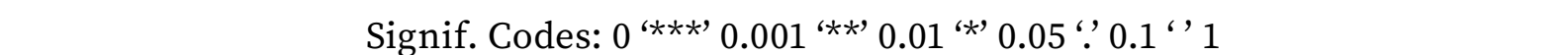 \\
\hline
\end{tabular}

Box plots of the individual conditions are shown in Figure 3. Means and medians of each condition are in Table 5. 
Figure 3. Detailed graph: means of conditions

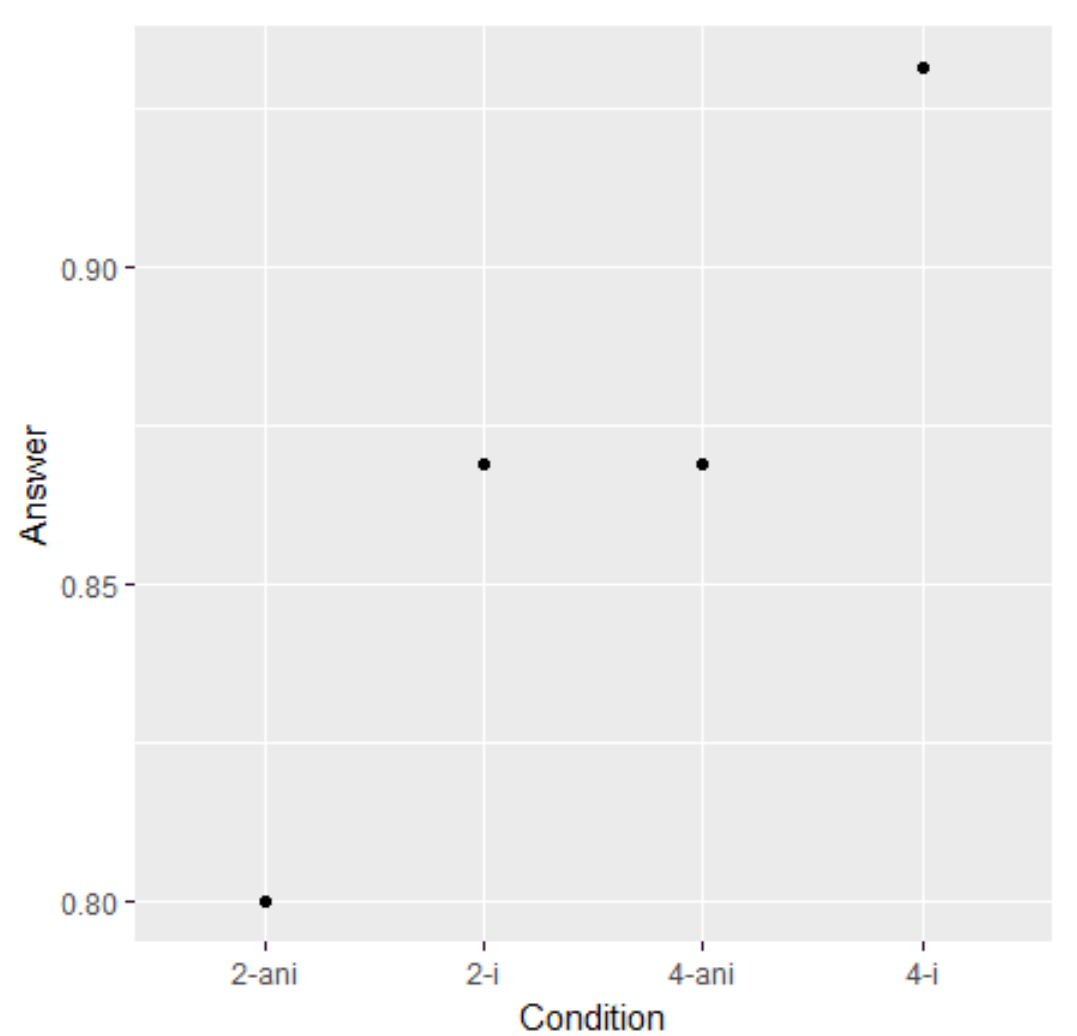

Table 5. Means and medians of conditions

\begin{tabular}{|c|c|c|}
\hline Condition & Means & Medians \\
\hline 2 -ani & 0.80000 & 1 \\
\hline $2-\mathrm{i}$ & 0.86875 & 1 \\
\hline 4 -ani & 0.86875 & 1 \\
\hline $4-\mathrm{i}$ & 0.93125 & 1 \\
\hline
\end{tabular}

The statistical analysis shows (i) that the mean success rate of tested sentences with $i$ and ani was very high, (i) that there is no statistical difference between grade 2 and grade 4 in sentences with $i$, (iii) that there is no statistical difference between grade 2 and grade 4 in sentences with ani, and last but not least (iv) that children aged 7-10 have already acquired both expressions $i$ and ani and they understand the scale of likelihood (the pragmatic aspect).

\section{Summary and conclusion}

The experimental results show a tendency of children aged 7-10 to have already acquired i/ani, which was proved by statistical analysis. Our initial four hypotheses were not confirmed. The experimental results show that children in grade 2 understand scalar expressions. Both $i$ and ani are acquired approximately at the same time, although 
children made fewer mistakes in sentences with $i$. The middle options were marginal, which corresponds to Kim's (2011) finding. Even though there is only one lexical item even in English as opposed to Czech i/ani, children have to learn the pragmatic aspect, i.e., the likelihood, in both languages. Moreover, children have to learn how the likelihood changes with respect to positive/negative sentences.

Since the particles are generally marginally included in the methodological plan for language education at primary schools, we assume that the acquisition of expressions $i$ ani depends on the individual development of the child's cognitive and pragmatic competences independently of language education. Getting to know how language is acquired is crucial for many areas connected to child development. In the current Czech linguistic environment and renewed interest in child language the main attention has been paid to pre-school age language acquisition, e.g. Smolík \& Bláhová (2017); Smolík \& Seidlová Málková (2014); Saicová Římalová (2013); Doleží (2014); Mertins et al. (2014). It might seem that once children enter school there are not many things going on linguistically speaking. Opposite is the case, though. With our study we tried to contribute to the understanding of how later phases of acquisition work and support it by concrete results and analyses and not impressions. The results might have interesting implications for mother tongue as well as second or foreign language teaching in understanding whether, when and how to teach or confront children with particular linguistic phenomena so that they can master them fully. To see when and how exactly the $i$ and ani-expressions are acquired by Czech children we have to pay attention to younger children and carry out further research with first grade and pre-school age children.

\section{References}

Crnič, L. 2011. Getting Even [Unpublished PhD dissertation]. Massachusetts Institute of Technology.

Doleží, L. 2014. Reduction and elaboration in Czech coordinate structures: An elicited imitation task. In: L. Veselovská \& M. Janebová (eds.), Complex Visibles Out There. Proceedings of the Olomouc Linguistics Colloquium 2014: Language Use and Linguistic Structure, 387-400. Olomouc: Univerzita Palackého.

Fox, D. \& Hackl, M. 2006. The universal density of measurement. Linguistics and Philosophy 29(5): 537-586.

Karttunen, L. \& Karttunen, F. 1977. Even questions. In: NELS 7: Proceedings of the Seventh Annual Meeting of the North Eastern Linguistic Society, 115-34. Cambridge: MIT.

Kim, S. 2011. Focus Particles at Syntactic, Semantic and Pragmatic Interfaces: The Acquisition of only and even in English [Unpublished PhD dissertation]. University of Hawaii at Manoa, Manoa.

Krifka, M. 1995. The semantics and pragmatics of polarity items. Linguistic Analysis 25 (3-4): 209-57. 
Lamprecht, A., Šlosar, D. \& Bauer, J. 1986. Historická mluvnice češtiny. Praha: Státní pedagogické nakladatelství.

Mertins, B. et al. 2014. Identifikace konstituentu kompozit u předškolních dětí. Naše řě 97(3): 146-165.

Newman, E., Gowda, Y., Rosenstein, L. \& Hackl, M. 2018. Polarity sensitivity of even in early child grammar. GALANA 8, Indiana University, Bloomington. Poster.

Rámcový vzdělávací program pro základní vzdělávání [online]. Praha: MŠMT, 3-2017. Available from: http://www.nuv.cz/t/rvp-pro-zakladni-vzdelavani.

Rooth, M. 1985. Association with Focus [Unpublished PhD dissertation]. University of Massachusetts.

Saicová Římalová, L. 2013. Kdyžzačináme mluvit... Lingvisticky' pohled na rane' projevy česky hovořicího ditěte. Praha: Práce Filozoficke' fakulty Univerzity Karlovy, Varia.

Sauerland, U. 2004. Scalar implicatures in complex sentences. Linguistics and Philosophy 27(3): 367-391.

Smolík, F. \& Bláhová, V. 2017. Comprehension of verb number morphemes in Czech children: Singular and plural show different relations to age and vocabulary. First Language 37(1): 42-57.

Smolík, F. \& Seidlová Málková, G. 2014. Vývoj jazykových schopnosti’v předškolním věku. Praha: Grada.

Spector, B. 2007. Scalar implicatures: Exhaustivity and Gricean reasoning. Questions in Dynamic Semantics 17: 225-249.

Šafratová, I. 2018. Negation, NPI and Scales of Likelihood: An Experimental Study. [Unpublished Master's thesis]. Masaryk University.

Školní vzdělávací program pro základní vzdělání ZŠ a MŠ Rovečné. 2015. Rovečné.

$* * *$

Linda Doleží is a language teacher and teacher trainer. She works as an Assistant Professor at Masaryk University Language Centre and at the Department of Czech Language of Faculty of Arts at Masaryk University. She focuses on teaching methodology, language acquisition and psycho- and neurolinguistics in multilingual contexts. Her current interests include language attrition phenomena and the role of emotions and trauma in language acquisition and attrition.

Petra Kurfürstová is a graduate of upper secondary school teacher training in Czech language and literature at the Faculty of Arts at Masaryk University. In her M. A. thesis she dealt with the acquisition of scalar particles $i$ and ani in Czech children. During her studies she was interested not only in child language acquisition and in teaching methodology but also in teaching Czech as a second language. 
Iveta Šafratová is a second-year doctoral student in a joint supervision of doctoral studies at the Department of Linguistics at Masaryk University and at the Seminar for English Philology at Georg-August-Universität Göttingen. She focuses on the syntaxsemantic-pragmatic interface and she is also interested in experimental linguistics. She is working on negation, especially scalar particles and polarity items in Czech. 